\title{
Language and HIV/AIDS
}




\section{CRITICAL LANGUAGE AND LITERACY STUDIES}

Series Editors: Vaidehi Ramanathan, University of California, USA; Bonny Norton, University of British Columbia, Canada and Alastair Pennycook, University of Technology, Sydney, Australia

Critical Language and Literacy Studies is an international series that encourages monographs directly addressing issues of power (its flows, inequities, distributions and trajectories) in a variety of language- and literacy-related realms. The aim with this series is twofold: (1) to cultivate scholarship that openly engages with social, political and historical dimensions in language and literacy studies, and (2) to widen disciplinary horizons by encouraging new work on topics that have received little focus and that use innovative theoretical frameworks.

Full details of all the books in this series and of all our other publications can be found on http:/ / www.multilingual-matters.com, or by writing to Multilingual Matters, St Nicholas House, 31-34 High Street, Bristol, BS1 2AW, UK.

\section{Other books in the series:}

Collaborative Research in Multilingual Classrooms

Corey Denos, Kelleen Toohey, Kathy Neilson and Bonnie Waterstone

English as a Local Language: Post-colonial Identities and Multilingual Practices Christina Higgins

The Idea of English in Japan: Ideology and the Evolution of a Global Language Philip Seargeant 


\section{CRITICAL LANGUAGE AND LITERACY STUDIES}

Series Editors: Vaidehi Ramanathan, Bonny Norton and Alastair Pennycook

\section{Language and HIV/AIDS}

Edited by

Christina Higgins and Bonny Norton

\section{MULTILINGUAL MATTERS}

Bristol • Buffalo • Toronto 


\section{Library of Congress Cataloging in Publication Data}

A catalog record for this book is available from the Library of Congress.

Language and HIV / Aids/Edited by Christina Higgins and Bonny Norton.

Critical language and literacy studies: 5

Includes bibliographical references and index.

1. AIDS (Disease)--Prevention--Study and teaching. 2. HIV infections--Prevention-Study and teaching.

I. Higgins, Christina. II. Norton, Bonny

RA643.8.L36 2009

$614.5^{\prime} 99392-$ dc22 2009033460

\section{British Library Cataloguing in Publication Data}

A catalogue entry for this book is available from the British Library.

ISBN-13: 978-1-84769-220-7 (hbk)

ISBN-13: 978-1-84769-219-1 (pbk)

\section{Multilingual Matters}

UK: St Nicholas House, 31-34 High Street, Bristol, BS1 2AW, UK.

USA: UTP, 2250 Military Road, Tonawanda, NY 14150, USA.

Canada: UTP, 5201 Dufferin Street, North York, Ontario, M3H 5T8, Canada.

Copyright (C) 2010 Christina Higgins, Bonny Norton and the authors of individual chapters.

All rights reserved. No part of this work may be reproduced in any form or by any means without permission in writing from the publisher.

The policy of Multilingual Matters/Channel View Publications is to use papers that are natural, renewable and recyclable products, made from wood grown in sustainable forests. In the manufacturing process of our books, and to further support our policy, preference is given to printers that have FSC and PEFC Chain of Custody certification. The FSC and/or PEFC logos will appear on those books where full certification has been granted to the printer concerned.

Typeset by Techset Composition Ltd., Salisbury, UK.

Printed and bound in Great Britain by the MPG Books Group. 